\title{
Komparasi Kinerja Perbankan Syariah dengan Bank Konvensional: Suatu Studi Literatur
}

\author{
Fany Indriyani \\ Peserta Program Pascasarjana Universitas Diponegoro \\ Email: fanyfeuii.arifin@,gmail.com
}

\begin{abstract}
This article looks at how the development of Islamic banking performance in recent years when compared with the performance of conventional banks. This article compares the results of several studies that have been conducted on the two types of banking. The previous study using financial ratios to look at the financial performance of banks. Based on some previous research, there are several measuring tool used to view the performance of both Islamic and conventional banking, is to approach CAMELS (Capital, Assets, Management, Earnings, Liquidity and Market Risk Sensitivity). The ratio used in CAMEL ratios include profitability ratios, liquidity risk and credit risk. In general the results obtained from these studies are not found significant differences in the performance of Islamic and conventional banking. As for some of the differences that exist more on smaller credit risk in Islamic banks and the greater liquidity in Islamic banks. This is a good signal for the development of Islamic banking both nationally and internationally.
\end{abstract}

Keywords: Islamic banks, conventional, performance, CAMELS

\begin{abstract}
Abstrak
Artikel ini melihat bagaimana perkembangan kinerja perbankan syariah beberapa tahun belakangan ini jika dibandingkan dengan kinerja bank konvensional. Artikel ini membandingkan hasil beberapa penelitian yang telah dilakukan terhadap kedua jenis perbankan tersebut. Penelitian terdahulu menggunakan beberapa rasio keuangan untuk melihat kinerja keuangan perbankan. Berdasarkan beberapa penelitian terdahulu terdapat beberapa alat ukur yang digunakan untuk melihat kinerja baik perbankan syariah maupun konvensional, yaitu dengan pendekatan CAMELS. Adapun rasio yang digunakan dalam rasio CAMEL meliputi rasio profitability, liquidity
\end{abstract}


risk, dan credit risk. Secara umum hasil yang diperoleh dari beberapa penelitian tersebut adalah tidak ditemukan adanya perbedaan yang signifikan dalam kinerja perbankan syariah maupun konvensional. Adapun beberapa perbedaan yang ada lebih pada risiko kredit yang lebih kecil pada bank syariah dan likuiditas yang lebih besar pada bank syariah. Hal ini merupakan sinyal yang baik bagi perkembangan perbankan syariah baik secara nasional maupun internasional.

Keywords: Perbankan syariah, konvensional, kinerja, CAMELS

\section{Pendahuluan}

Berdasarkan laporan Bank Indonesia tahun 2015, industri perbankan syariah saat ini menunjukkan akselerasi pertumbuhan yang tinggi sebesar $40,2 \%$ pertahun dalam lima tahun terakhir (2007-2011), diantara pertumbuhan perbankan nasional sebesar $16,7 \%$ pertahun. Oleh karena itu, industri perbankan syariah dijuluki sebagai 'the fastest growing industry'. Peningkatan ini dipicu oleh peningkatan kinerja industri perbankan syariah baik dari sisi penghimpunan dana maupun penyaluran pembiayaan.

Di Indonesia kesehatan kinerja perbankan diukur oleh Bank Indonesia, sebagai otoritas tertinggi pemegang kebijakan perbankan. Setiap tahun Bank Indonesia harus melaporkan kinerja semua bank yang ada di Indonesia untuk melihat tingkat kesehatan perbankan secara nasional. Bank Indonesia mengukur peningkatan kinerja industri perbankan syariah melalui berbagai rasio keuangan. Bank Indonesia telah menetapkan aturan No. 9/1/ PBI/2007 tentang Sistem Penilaian Tingkat Kesehatan Bank Umum berdasarkan prinsip Syariah.

Tidak hanya di Indonesia, beberapa Negara yang juga memiliki industry perbankan syariah juga menerapkan metode pengukuran yang sama, yaitu dengan menggunakan analisis rasio keuangan. Terbukti maraknya penelitian tentang kinerja perbankan syariah dengan alat ukur yang sama, yaitu kinerja.

Beberapa penelitian tentang perkembangan perbankan syariah telah dilakukan dalam kurun waktu sepuluh tahun belakangan ini. Indicator paling banyak yang digunakan dalam mengukur perkembangan perbankan syariah 
adalah dengan pengukuran kinerja. Penelitian tentang kinerja perbankan syariah pada awalnya dilakukan oleh Samad dan Hassan (1999), dengan mengambil latar belakang perbankan syariah di Malaysia, penelitian ini melihat perkembangan kinerja bank syariah melalui beberapa rasio yaitu: profitability, liquidity, risk dansolvency. Penelitian ini berhasil membuktikan bahwa bank syariah lebih likuid dan lebih kecil risikonya dibandingkan dengan bank konvensional. Selanjutnya penelitian mengenai kinerja perbankan syariah mulai berkembang.

Penelitian tentang perbankan syariah banyak berkembang dinegaranegara yang mayoritas penduduknya adalah muslim, seperti Malaysia, Indonesia, Pakistan, Banglades, GCC dan UAE. Sebagaimana yang dilakukan oleh Samad (2004) yang kinerja bank syariah setelah periode Gulf War, dengan indicator profitability, liquidity risk, dan credit risk dengan latar belakang Bahrain. Penelitian ini tidak menemukan adanya perbedaan yang signifikan antara kinerja perbankan syariah dengan konvensional.

Penelitian lintas Negara juga dilakukan oleh Bader,Mohamad, Ariff, dan Hassan (2008) dengan menggunakan sampel 21 negara selama lima belas tahun (1990-2005) terhadap 43 bank Islam dan 37 bank konvensional. Penelitian ini mengukur efisiensi cost, revenue dan profit melalui umur, ukuran, dan wilayah masing-masing sampel. Hasil yang diperoleh adalah tidak ditemukan adanya perbedaan yang signifikan antara efisiensi bank syariah dengan bank konvensional.

Sementara itu beberapa penelitian yang dilakukan di Indonesia terkait kinerja bank syariah juga tengah marak dilakukan. hal ini dilakukan oleh Ika dan Abdullah (2011) yang melihat bagaimana kinerja perbankan syariah bila dibandingkan dengan perbankan konvensional dengan menggunakan rasio keuangan profitability, liquidity, risk and solvency dan efficiency. Penelitian ini juga tidak dapat menemukan perbedaan yang signifikan antara kinerja perbankan syariah dengan konvensional, kecuali untuk likuiditasnya. Likuiditas perbankan syariah lebih baik dibandingkan bank konvensional.

Maraknya penelitian mengenai kinerja perbankan syariah khususnya pada tiga decade terakhir, sangat menarik untuk dicermati. Banyak peneliti berusaha untuk mencari factor apa yang sangat menentukan kinerja perbankan khususnya perbankan syariah. Artikel ini bertujuan untuk 
mereview beberapa penelitian yang telah dilakukan, guna melihat kelemahan dan kelebihan beberapa penelitian tersebut sehingga dapat dijadikan acuan untuk meneliti lebih lanjut. Artikel ini terdiri dari 4 bagian, yaitu (1) pendahuluan, (2) perbedaan mendasar antara Bank Syariah dengan Bank Konvensional, (3) Indikator Pengukuran Kinerja Perbankan, (4) Survey literature dan (5) kesimpulan.

\section{Perbedaan mendasar antara bank syariah dengan bank konvensional}

Untuk memahami kekuatan dan kelemahan bank Islam terkait kinerjanya, maka perlu diketahui bagaimana lingkungan bank tersebut beroperasi. Menurut Samad (2004) institusi keuangan syariah harus patuh pada empat prinsip dasar, yaitu:

1) Semua transaksi harus bebas dari riba

Al-quran menyebutkan secara eksplisit bahwa semua transaksi jual beli harus bebas dari riba (Al-Baqarah: 185). Namun tidak dijelaskan apakah bunga termasuk dalam riba, sehingga terjadi kesepakan secara umum dilakangan umat muslim bahwa riba mencakup semua biaya atas pinjaman. Sehingga menerima bunga sebagaimana yang dilakukan bank konvensional dilarang dalam dunia perbankan dan keuangan Islam.

2) Semua aktivitas transaksi harus bebas dari spekulasi (gharar)

Gharar adalah spekulasi yang sangat dilarang dalam Islam. Islam memperbolehkan pengambilan risiko dalam transaksi bisnis namun melarang adanya spekulasi. Aktivitas yang melibatkan elemen spekulasi seperti pembelian saham dengan harga yang sangat rendah, dan menjualnya dengan sangat tinggi. Sementara bank konvensional tidak terkendala dengan investasi yang melibatkan spekulasi.

3) Harus mengimplementasikan zakat sebagai kewajiban dalam Islam Zakat merupakan kewajiban pembayaran pajak dari si kaya kepada simiskin untuk kesejahteraan bersama. Zakat merupakan salah satu rukun Islam yang wajib diimani oleh setiap muslim. Perbankan Islam memiliki kewajiban untuk memotong zakat tiap kekayaan yang dimiliki nasabahnya, sehingga terjadi dual pembayaran, yaitu zakat dan administrasi. Sementara itu bank konvensional hanya menerapkan 
pembayaran administrasi saja.Tidak mencampur produksi atau konsumsi barang dan jasa yang illegal (haram)

Dalam Islam investasi dan produksi sangat ketat. Muslim tidak diperbolehkan untuk berinvestasi dalam produksi, distribusi dan konsumsi perusahaan yang terkait alcohol, babi, judi, narkotika, dll, meskipun perusahaan tersebut sangat menguntungkan.

Begitupula penyediaan dana untuk aktivitas tersebut terlarang dalam Islam. Batasan dalam investasi dan pembiayaan sangat membatasi kemampuan bank syariah dalam menghasilkan keuntungan. Disisi lain, bank konvensional tidak menghadapi kendala tersebut dalam kegiatan pembiayaan dan investasinya.

Elemen penting dalam bank dan lembaga keuangan syariah adalah konsep PLS (Profit and Loss Sharing). Berdasarkan prinsip tersebut terdapat beberapa tipe instrument keuangan yang tersedia dipasar. Beberapa instrument tersebut adalah Musyarakah, Mudarabah, Murabahah, Ijarah, Istisna, qordul hasan. Keberadaan produk-produk ini dapat menggantikan ketidakadaan bunga dalam transaksi bank syariah (Siddiqi, 1983a; Ahmad, 1984; Iqbal and Mirakhor,1987; Ahmad, 1987).

\section{Indikator pengukuran kinerja perbankan}

Pengukuran indicator kinerja Perbankan Syariah yang paling umum digunakan adalah pendekatan CAMELS (Capital, Asset, Management, Earning, Liquidity dan Sensitivity Market Risk). Metode pengukuran ini merupakan alat ukur resmi yang digunakan Bank Indonesia dalam mengukur kesehatan Bank Syariah di Indonesia, sehingga sangat sering dipergunakan dalam penelitian. Penelitian dalam sepuluh tahun terakhir dapat menunjukkan faktor apa yang paling berpengaruh dalam peningkatan kinerja perbankan syariah baik didalam negeri maupun diluar negeri.

CAMEL merupakan suatu analisis keuangan suatu bank dan penilaian manajemen suatu bank yang ditetapkan oleh Bank Indonesia untuk mengetahui tingkat kesehatan bank dari bank yang bersangkutan (Kasmir, 2000). Penilaian kesehatan bank meliputi 5 aspek yaitu : 
1) Capital, untuk rasio kecukupan modal

Menurut Kasmir (2000), capital (permodalan) yang dinilai adalah permodalan yang didasarkan kepada kewajiban penyediaan modal minimum bank. Penilaian tersebut didasarkan kepada CAR (Capital Adequancy Ratio) yang telah ditetapkan oleh Bank Indonesia. Perbandingan rasio tersebut adalah rasio modal terhadap Aktiva Tertimbang Menurut Resiko (ATMR) dan sesuai dengan ketentuan Bank Indonesia tentang jumlah minimal CAR yaitu $8 \%$.Assets, untuk rasio kualitas aktiva produktif atau assets

2) Management, untuk rasio-rasio rentabilitas bank

Menurut Kamsir (2008), kualitas aset digunakan untuk menilai jenisjenis asset yang dimiliki oleh bank. Penialaian asset harus sesuai dengan peraturan yang ditetapkan oleh Bank Indonesia yang didasarkan pada dua rasio yaitu :

a. Rasio aktiva produktif yang diklasifikasikan (APYD) terhadap aktiva produktif (AP).

b. Rasio penyisihan penghapusan aktiva produktif yang dibentuk oleh bank terhadap penyisihan penghapusan aktiva produktif yang wajib dibentuk oleh bank.

Menurut Kasmir (2003) dalam mengelola kegiatan bank sehari-hari juga harus dinilai kualitas manajemennya. Kualitas manajemen juga dilihat dari pendidikan serta pengalaman para karyawan dalam menangani berbagai kasus yang terjadi, dalam aspek ini yang dinilai adalah manajemen permodalan, manajemen aktiva, manajemen umum, manajemen rentabilitas, dan manajemen likuiditas.

3) Earning, untuk rasio-rasio rentabilitas bank

Menurut Kasmir (2008) Earning (rentabilitas merupakan kemampuan bank dalam meningkatkan labanya, apakah setiap periode atau untuk mengukur tingkat efesiensi usaha dan profitabilitas yang dicapai oleh bank yang bersangkutan. Bank yang sehat yang diukur secara rentabilitas yang terus meningkat, penilaian juga dilakukan dengan:

a. Rasio laba bersih terhadap total asset (ROA).

b. Perbandingan biaya operasi dengan pendapatan operasi (BOPO). 
4) Liquidity, untuk rasio-rasio likuiditas bank

Menurut Kasmir (2008) sebuah bank dikatakan likuid apabila bank yang bersangkutan dapat membayar semua hutang-hutangnya, terutama simpanan tabungan, giro, deposito pada saat ditagih dan dapat pula memenuhi semua permohonan kredit yang layak dibiayai. Secara umum rasio ini merupakan rasio antara jumlah aktiva lancar dengan hutang lancar, yang dianalisi dalam rasio ini, adalah:

1) Rasio kewajiban bersih Call Money terhadap aktiva.

2) Rasio kredit terhadap dana yang diterima oleh bank seperti giro, tabungan, deposito dan lain-lain.

\section{Penelitian terdahulu}

Penelitian terdahulu tentang kinerja perbankan syariah pernah dilakukan oleh Cole and Gunther (1998), Tarawneh (2006),Aikaeli (2008), Dash and Das (2010) dan Kauser dan Saba (2012). Sementara itu didalam negeri, studi inipun dilakukan oleh Herdinigtyas, Winny, dan Almilia(2006), Kusumo dan Kartiko (2002),dan Sudiyatno dan Suroso (2010). Secara umum aspek kinerja dalam penelitian terdahulu menggambarkan bagaimana kondisi keuangan bank dalam satu periode baik melalui factor penghimpunan dana maupun penyaluran dana. Melalui studi ini dapat diketahui dimana kekuatan dan kelemahan yang dapat dicapai oleh suatu bank (Kusumo, 2008).

Pada tahun 2012 Kauser dan Saba melakukan riset dengan latar belakang Perbankan Islam di Pakistan baik murni syariah, campuran, maupun konvensional. Penelitian ini menggunakan indicator CAMELS untuk mengukur kinerja ketiga bank tersebut. Berdasarkan analisis yang dilakukan ditemukan adanya perbedaan rata-rata rasio CAMELS pada ketiga jenis bank. Perbedaan tersebut meliputi hal-hal sebagai berikut.

\section{Modal (Capital)}

Salah satu rasio modal yang dipergunakan adalah CAR (Capital to Asset Ratio) yang merupakan indicator untuk mengukur kemampuan bank dalam menanggung risiko kredit yang tidak tertagih dengan modalnya. Dalam penelitian ini diketahui bahwa pada bank murni Islam dan bank 
konvensional terjadi penurunan dalam kurun waktu studi ini dilakukan. sementara itu untuk bank Islam yang menginduk pada bank konvensional cendrung lebih stabil dalam mempertahankan modalnya.

\begin{abstract}
Aktiva (Asset)
Pengukuran rasio asset dilakukan untuk mengetahui kemampuan kualitas aktiva produktif yang dimiliki oleh bank. Pengukuran dilakukan terhadap empat aspek (dalam penelitian ini) yaitu terhadap pinjaman, portofolio pinjaman, kerugian pinjaman dan cadangan kerugian pinjaman. Kecendrungan yang terjadi pada penelitian ini adalah pada bank konvensional dan bank Islam yang menginduk pada bank konvensional cenderung naik sebentar kemudian turun, sementara itu untuk bank Islam murni akan mengalami peningkatan.
\end{abstract}

\title{
Manajemen
}

Kompetensi manajemen dalam penelitian ditentukan melalui aktivitas pinjaman oleh pihak staff, aktivitas pinjaman oleh pihak manajemen, portofolio staff, nilai uang yang dikeluarkan, dan biaya yang dikeluarkan untuk peminjaman tersebut. Pada Bank Islam kecendrungan pinjaman oleh staff manajemen kecil, sedangkan bank konvensional memiliki kecendrungan lebih besar untuk peminjaman oleh pihak staf manajemen.

\section{Earning}

Rasio earning (rentabilitas) adalah kemampuan bank dalam menghasilkan laba dibandingkan modal yang digunakan selama periode tertentu(Ayuningtyas, Yuningngsih, dan Rusliansyah; 2011). Penelitian ini menggunakan enam jenis rasio untuk melihat tren earning pada perbankan Islam di Pakistan. Rasio atas earning dilakukan terhadap aset produktif, total aset, cost financial, biaya administrative, operating self-sufficiency danfinancial self-sufficiency ratio.

Hasil penelitian ini menunjukkan bagaimana asset produktif meningkat pada awal periode penelitian (2007) dan cendrung stabil pada periode berikutnya (2008-2010). Total asset pada bank konvensional dan 
bank Islam yang berinduk pada bank konvensional, menurun selama periode penelitian, meskipun secara kuantitas meningkat pada tahun 2007 dan relative stabil pada tahun 2010. Sementara itu untuk rata-rata cost financial untuk ketiga bank, meningkat pada periode tahun 2006-2009.

Untuk biaya administrative, pada bank konvensional mengalami kenaikan meskipun kecil. Sementara itu untuk bank islam yang menginduk pada bank konvensional dan bank Islam sangat kecil. Untuk financial selfsufficiency ratio bank Islam cendrung stabil dalam periode penelitian. Sementara itu untuk bank konvensional mengalami penurunan diawal periode penelitian, namun mengalami peningkatan ditahun 2010. Sementara itu untuk bank Islam yang menginduk pada bank konvensional, cendrung stabil selama periode penelitian.

\section{Liquidity}

Pada penelitian ini likuiditas diukur dengan satu rasio saja yaitu current ratio. Tren yang terjadi untuk ketiga bank adalah menurun pada tahun 2007, kemudian meningkat meskipun kecil pada tahun 2008 untuk bank konvensional, dan peningkatan yang sangat besar pada tahun 2010 . Sementara kenaikan untuk bank Islam dan bank Islam yang menginduk pada bank konvensional hanya mengalami kenaikan yang sangat kecil.

Berdasarkan hasil yang diperoleh dari penelitian ini dapat disimpulkan bahwa bank Islam memiliki modal yang lebih stabil dan kualitas asset yang lebih baik dibandingkan bank Islam yang menginduk pada bank konvensional. Bank Islam secara umum memiliki manajemen yang lebih kompeten dibandingkan bank konvensional. Sementara itu Earning yang terbaik dimiliki oleh bank Islam yang menginduk pada bank konvensional.

Hasil yang diperoleh ini cukup berbeda dengan penelitian yang terdahulu, yang dapat menyimpulkan bahwa kinerja bank Islam lebih menguntungkan, likuiditasnya kecil, risiko lebih kecil, dan lebih efisien dibandingkan bank konvensional (Samad dan Hassan, 2000). Hal ini disebabkan karena perkembangan perbankan Islam di Pakistan yang baru terjadi pada tahun 2003, yang masih membutuhkan berbagai promosi dan inovasi dalam system perbankan di Pakistan. Terlebih lagi keberadaan bank konvesional yang telah mengakar dan sangat cepat dalam melayani kebutuhan sector keuangan. 
Sehrish, Saleem, Yasir, dan Shehzad (2012) melakukan pembandingan kinerja perbankan syariah dengan konvensional di Pakistan dalam kurun waktu empat tahun yaitu 2007-2011. Penelitian ini dipicu oleh keberadaan perbankan syariah sebagai pendatang baru dalam industry perbankan nasio nasional Pakistan, sehingga untuk dapat memberikan gambaran bagaimana posisi perbankan syariah terhadap stakeholder, maka posisi keuangan perbankan syariah dianalisis dan dibandingkan dengan perbankan konvensional.

Riset dilakukan dengan menggunakan enam jenis rasio terhadap delapan sampel bank. Rasio tersebut terbagi atas tiga rasio yaitu rasio untuk mengukur kinerja, rasio efisiensi dan rasio risiko kredit. Rasio kinerja terdiri at as rasio profitabilitas, ROA (Return On Asset) dan ROD (Return on Deposit). Rasio efisiensi terdiri dari Asset Utilization (AU) dan Operating Efficiency (OE). Sementara itu rasio risiko kredit terdiri atas Equity to Net Loan Ratio (EQL) dan Total Impaired Loan to Gross Loan Ratio (IMLGL).

Hasil analisis menyatakan bahwa bank Islam memiliki kinerja yang baik pada tiga tahun pertama periode studi dilakukan, namun bank konvensional memiliki profit yang lebih baik. Meskipun demikian pertumbuhan profit bank syariah yang terus meningkat diharapkan mampu melampaui profitabilitas bank konvensional. Dikarenakan bank syariah masih dalam tahap awal tumbuh dalam industry perbankan nasional Pakistan, maka sangat sulit untuk membandingkan tingkat profitabilitas perbankan syariah dengan perbankan konvensional. Namun demikian hasil penelitian ini menunjukkan tidak ada perbedaan yang signifikan dalam kinerja profitabilitas perbankan syariah dengan konvensional.

Melalui sisi kinerja efisiensi diperoleh hasil bahwa sector Islam tidak dapat efisien dalam biaya asset dan operasional khususnya dalam menghasilkan revenue yang tinggi. Asset bank syariah mengalami peningkatan pada tahun 2008, yang turut meningkatkan revenue mereka. Peningkatan revenue ini disebabkan karena bank syariah masih memanfaatkan asset yang mereka miliki untuk meningkatkan kinerjanya. Sehingga untuk meningkatkan kinerja revenue-nya, bank syariah menggunakan biaya yang sangat tinggi sehingga kinerja efisiensi belum bisa tercapai dengan maksimal dibandingkan bank konvensional. 
Dalam hal pengukuran resiko kredit, bank syariah memiliki kapasitas yang lebih baik dalam menyerap terjadinya krisis keuangan dan menyusutkan risiko pinjaman. Meskipun memiliki risiko yang rendah, namun kemampuan bank untuk menyiapkan kerugian karena pinjaman masih rendah. Situasi ini haris diwaspadai oleh perbankan syariah di Pakistan dimasa yang akan datang. Namun demikian keadaan ini masih menunjukkan kerja yang memuaskan dari sector perbankan syariah.

Penelitian oleh Loghod (2010) membandingkan kinerja keuangan sistem dual banking yaitu Islam dan konvensional. Tujuannya adalah untuk melihat kinerja kedua sistem tersebut ketika dijalankan secara berdampingan. Penelitian ini menggunakan sampel di negara-negara aliansi timur tengah (Gulf Cooperation Council) untuk membandingkan kinerja keuangan yang terdiri dari tiga elemen, yaitu profitabilitas, likuiditas, dan struktur. Periode penelitian dilakukan dalam lima tahun yaitu 2000-2005. Penelitian ini menggunakan metode kuantitatif untuk memastikan perbedaan kinerja antara kedua tipe bank. Hasil yang diperoleh dari penelitian ini adalah sebagai berikut:

a. Pangsa pasar yang dicari melalui total asset diperoleh hasil bahwa bank konvensional masih mendominasi pasar di Negara GCC. Namun demikian bank konvensional kehilangan sebesar 2,07\%, dan pertumbuhan bank syariah meningkat dari $12,09 \%$ pada tahun 2000 menjadi $14,16 \%$ ditahun 2005. Ini menandakan pertumbuhan dunia perbankan syariah yang cukup cepat.

b. Analisis rasio profitabilitas menggunakan ROA, ROE, dan rasio pembayaran dividen menunjukkan tidak ada perbedaan yang signifikan diantara kedua tipe bank. Namun jika dilihat dari rata-rata tiap tipe bank diindustrinya ditiap Negara, maka perbankan syariah menunjukkan rasio yang cukup tinggi kecuali di Unit Emirat Arab. Hal ini sangat dimungkinkan karena menentukan profitabilitas ditentukan oleh pasar dan manajemen selain kinerja keuangan perbankan itu sendiri.

c. Rasio likuiditas merupakan hal penting untuk kelangsungan hidup perbankan tersebut. Hasil penelitian ini menunjukkan bahwa bank konvensional lebih beresiko dibandingkan bank syariah. 
d. Analisis berbagai struktur rasio yang meliputi:

1) Rasio hutang terhadap asset yang menunjukkan bahwa bank konvensional lebih bergantung kepada hutang luar.

2) Rasio pitang terhadap asset menunjukkan bahwa konsumen lebih tertarik pada instrument bank syariah karena lebih sesuai dengan syariah.

3) Rasio deposito terhadap ekuitas memiliki hasil yang beragam. Pada Negara Kuwait dan Qatar rasio bank syariah lebih tinggi dari bank konvensional. Sementara di Bahrain, Arab Saudi dan Unit Emirat Arab, menunjukkan kebalikannya.

4) Rasio asset tetap terhadap asset tinggi pada bank syariah. Hal ini disebabkan instrument bank Islam seperti Murabahah, Ijarah dapat meningkatkan nilai asset tetap perusahaan.

5) Secara statistic tidak ada perbedaan dalam tingkat pertumbuhan internal

6) Rasio hutang/piutang terhadap deposit dan rasio hutang terhadap ekuitas lebih tinggi pada bank syariah. Hal ini menandakan bahwa bank syariah lebih banyak mendanai operasional daripada menerima deposito.

7) Rasio deposito terhadap ekuitas dan rasio investasi dan deposito terhadap asset, tinggi pada bank konvensional. Hal ini menunjukkan kemampuan bank konvensional meningkatkan operasionalnya melalui deposito dan investasi.

8) Rasio ekuitas terhadap asset juga tinggi pada bank konvensional. Hal ini menunjukkan struktur keuangan yang kuat dan kemungkinan kecil kesulitan keuangan pada bank.

Beberapa temuan dalam penelitian tersebut menguatkan argument bahwa pertumbuhan perbankan syariah mengalami perkembangan yang cukup pesat khususnya dinegara-negara GCC.

Merchant (2012) juga melakukan penelitian yang hampir sama namun studi dilakukan ketika pada waktu terjadi krisis dan setelah krisis. Pada penelitian ini Merchant (2012) lebih focus pada langkah-langkah yang diambil bank untuk mengurangi efek dari terjadinya krisis. Studi ini juga meng- 
gunakan indicator analisis kinerja dari bank Islam dan konvensional dan dilakukan dalam kurun waktu empat tahun (2008-2011). Analisis dilakukan terhadap 17 bank Islam dan 10 bank konvensional sebagai sampel di wilayah Negara yang tergabung dalam aliansi uni emirat Arab (Gulf Cooperation Council), dengan menggunakan rasio CAMEL.

Pengukuran menggunakan CAMEL meliputi beberapa rasio, yaitu:

a) Capital Adequacy

Analisis ini dilakukan untuk mengetahui bagaimana kemampuan bank dan manajemen dalam mengatasi kejutan saat terjadi krisis. Capital adequacy diukur dengan menggunakan rasio equitas terhadap total asset (EQTA). Dalam penelitian ini bank Islam memiliki nilai EQTA yang tinggi. Hal ini mengindikasikan bahwa bank Islam mampu mengkapitalisasikan asetnya dengan baik. Begitupula dengan bank konvensional yang juga mengalami peningkatan kapitalisasi asset.

b) Asset quality

Kualitas asset ditentukan guna membantu bank memahami risiko terkait pengungkapan bank kepada debitur. Dalam penelitian ini dihitung menggunakan cadangan kerugian piutang (LLR). Pada bank syariah LLR meningkat yang artinya besarnya risiko setelah krisis, sebagaimana terjadi pada bank konvensional. Prilaku bank baik Islam maupun konvensional untuk menghapus pinjaman yang tidak tertagih terakumulasi selama periode krisis. Identifikasi pinjaman tidak tertagih membuat profit bank meningkat. Namun, peningkatan ini tidak hanya disebabkan oleh hal tersebut, namun kedua bank mampu meraih profit setelah terjadinya krisis.

c) Management quality

Merupakan tolak ukur untuk memahami kewajiban manajemen untuk menjaga operasional perbankan berjalan mulus dan sesuai dengan kaidah. Pengukuran kualitas manajemen dilakukan dengan rasio kos terhadap income (COSR). Pada bank konvensional COSR menunjukkan kinerja yang baik, sementara pada bank syariah sangat buruk. Pada bank syariah COSR yang dihasilkan tinggi sehingga mengarah pada rendahnya profitabilitas setelah terjadinya krisis. 
d) Earnings

Merupakan parameter kinerja bank yang membantu bank untuk menentukan dana yang dihadiahkan kepada stakeholder-nya. Pengukurannya menggunakan dua metode, yaitu perputaran rata-rata asset (ROAA) dan perputaran rata-rata ekuitas (ROAE). ROAE menunjukkan kinerja yang baik masa pemulihan dari krisis. Namun demikian, bank konvensional mampu menunjukkan kinerja lebih baik dibandingkan bank syariah. Sementara itu untuk ROAA tidak menunjukkan perbedaan yang signifikan dalam masa pemulihan dari krisis baik untuk bank syariah maupun bank konvensional.

e) Liquidity

Parameter ini untuk membantu bank menetapkan dan mengevaluasi risiko yang dihadapi dan tidak dapat diprediksi sebagai penyebab utama kebangkrutan bank. Nilai likuiditas diukur dengan pinjaman bersih terhadap total asset (NLTA). Hasil yang diperoleh dalam penelitian ini tidak ada perbedaan yang signifikan baik bank syariah maupun bank konvensional, terhadap NLTA baik selama periode krisis maupun setelah krisis.

\section{Penut up}

Artikel ini melihat bagaimana kinerja perbankan Islam dan konvensional dalam berbagai perspektif. Berbagai pengukuran dengan menggunakan rasio keuangan menunjukkan tidak ada perbedaan besar dalam kinerja perbankan Islam dengan perbankan konvensional.

Penelitian-penelitian tersebut juga mampu membuktikan bahwa perbankan syariah, meskipun merupakan pendatang baru dalam industry perbankan, tetapi mampu sejajar dengan perbankan konvensional, bahkan beberapa penelitian menemukan tingkat risiko kredit yang lebih rendah pada bank syariah.

Berdasarkan hal tersebut dapat dipastikan bahwa istilah 'the fastest growing industry' dalam industry perbankan sangat tepat dialamatkan pada bank syariah. Semoga dengan semakin membaiknya kinerja perbankan mendukung keinginan nasabah khususnya nasabah muslim untuk beralih ke bank syariah. 


\section{Daftar Pustaka}

Ayuningtyas Y.M, Isna Yuningsih, Rusliansyah. 2011. "Analisis Rasio Camel Untuk Menilai Tingkat Kesehatan Pada Bank Muamalat." Indonesiaportalgaruda.com

Ahmad, Ausaf. 1987. "Development and Problems of Islamic Banks." Jeddah:Islamic Research and Training Institute. Islamic Development Bank

Ahmad, Ziauddin. 1984. "Concept and Models of Islamic Banking: An Assessment." Islamabad: International Institute of Islamic Economics.

Bader, M. K. I., Mohamad, S., Ariff, M., \& Hassan, T. 2008. "Cost, Revenue and Profit Efficiency of Islamic Versus Conventional Banks: International Evidence Using Data Envelopment Analysis." Islamic Economic Studies, 15(2) 23-76.

Herdinigtyas, Winny, and Luciana Spica Almilia. 2006. "Analisis Rasio CAMEL terhadap Prediksi Kondisi Bermasalah Pada Lembaga Perbankan Perioda 2000-2002." Jurnal Akuntansi dan Keuangan 7.2: pp-131.

Ika, S. R., dan Abdullah, N. 2011. "A Comparative Study of Financial Performance of Islamic Banks and Conventional Banks in Indonesia. International Journal of Business and Social Science, 2(15).

Iqbal, Zubair, and Abbas Mirakhor. 1987. "Islamic Banking." International Monetary Fund, Washington, D.C.

Kusumo, Willyanto Kartiko. 2002. "Analisis Rasio-Rasio Keuangan Sebagai Indikator dalam Memprediksi Potensi Kebangkrutan Perbankan di Indonesia." Disertasi. Program Pascasarjana Universitas Diponegoro.

Kusumo, Y. A. 2008. "Analisis Kinerja Keuangan Bank Syariah Mandiri Periode 2002-2007 (dengan Pendekatan PBI No. 9/1/PBI/2007)." Jurnal Ekonomi Islam La-Riba, 2(1), 109-131.

Loghod, H. A. 2010. "Do Islamic Banks Perform Better than Conventional Banks? Evidence from Gulf Cooperation Council Countries" (No. 1011). Arab Planning Institute-Kuwait, Information Center.

Merchant, I. P. 2012. "Empirical Study of Islamic Banks Versus Conventional Banks of GCC." Global Journal of Management and Business Research, 12(20).

Sudiyatno, B., \& Suroso, J. “Analisis Pengaruh Dana Pihak Ketiga, BOPO, CAR Dan LDR terhadap Kinerja Keuangan Pada Sektor Perbankan 
yang Go Public Di Bursa Efek Indonesia (BEI) (Periode 20052008)." Dinamika Keuangan dan Perbankan, 2(2), 2010.

Yue, P. 1992, "Data Envelopment Analysis and Commercial Bank Performance: A Primer with Applications to Missouri Banks," Working Papers, ICW Institute, University of Texas at Austin.

Samad, A., \& Hassan, M. K. "The Performance of Malaysian Islamic Bank during 1984-1997: An Exploratory Study." International Journal of Islamic Financial Services, 1(3), 1-14, 1999.

Samad, A. 2004. "Performance of Interest-free Islamic banks vis-a-vis Interest-based Conventional Banks of Bahrain." International Journal of Economics, Management and Accounting, 12 (2)

Siddiqi, Mohammad Nejatullah. 1983. Banking Without Interest. Islamic Foundation, Leicester. 